\title{
An ecological analysis of childhood-onset type 1 diabetes incidence and prevalence in Latin America
}

\author{
Fernando Collado-Mesa, ${ }^{1}$ Alberto Barceló, ${ }^{2}$ Kristopher L. Arheart, ${ }^{1}$ \\ and Sarah E. Messiah ${ }^{1}$
}

Suggested citation Collado-Mesa F, Barceló A, Arheart KL, Messiah SE. An ecological analysis of childhood-onset type 1 diabetes incidence and prevalence in Latin America. Rev Panam Salud Publica. 2004;15(6):388-94.

ABSTRACT Objective. To explore, for Latin America, by means of an ecological correlation analysis, the possible relationships between both the incidence and prevalence of childhood type 1 diabetes and selected hypothesized etiological factors, including race/ethnicity, geographical latitude, breastfeeding rates, per capita milk supply and coffee consumption, and wealth-related indicators such as infant mortality rate, life expectancy at birth, and national human development index.

Methods. Recently published data on incidence and prevalence of type 1 diabetes in children $\leq 14$ years of age in Latin American countries were utilized. Risk indicators were selected based on existing genetic and environmental hypotheses. Indicator data were obtained from publicly available resources. Spearman correlation coefficients were used to measure the association between both incidence and prevalence of type 1 diabetes and the selected indicators.

Results. A strong negative correlation was found between the proportion of Amerindians in a country's population and both incidence $(r=-0.75 ; \mathrm{P}=0.008)$ and estimated prevalence $(r=-0.78 ; \mathrm{P}<0.0001)$ of childhood type 1 diabetes. The per capita supply of milk showed a strong positive correlation with both incidence $(r=0.70 ; \mathrm{P}=0.025)$ and prevalence $(r=0.55$; $\mathrm{P}=0.018)$. Wealth-related indicators correlated with prevalence but not with incidence.

Conclusions. Our results suggest that the presence of the Amerindian component of the population in Latin America provides protection against childhood-onset type 1 diabetes. Our results also confirm the association previously reported in other countries and regions of the world of type 1 diabetes and milk consumption. Further studies are needed to develop and test potential genetic and environmental hypotheses that could help to better understand the interplay between genetic susceptibility and environment in type 1 diabetes across different ethnic groups.

Key words Diabetes mellitus, type I; ecology; ethnic groups; risk factors; Latin America; epidemiology.

The incidence of childhood type 1 diabetes varies widely around the world
(1-4). Earlier reports had indicated that there was a polar-equatorial gra-

\footnotetext{
1 University of Miami School of Medicine, Department of Epidemiology and Public Health, Miami, Florida, United States of America. Send correspondence and reprint requests to: Fernando ColladoMesa, Department of Epidemiology and Public Health, University of Miami School of Medicine,
}

Highland Professional Building, 1801 NW 9th AvStates of America; telephone: (305) 243-6979; fax: (305) 243-3384; e-mail: fcollado@med.miami.edu

2 Pan American Health Organization, Washington, D.C., United States of America. enue, Room 212-D, Miami, Florida 33136, United dient in the incidence of type 1 diabetes, but additional research has cast some doubts on the strength of this association. Instead, the variation in type 1 diabetes incidence appears to follow an ethnic and racial distribution in the world population (4). In general, Europoid populations have a higher inci- 
dence of type 1 diabetes than do nonEuropoid populations, although significant geographic differences are evident in incidence within each major ethnic group (4). Although childhood type 1 diabetes appears to be uncommon in most Latin American countries, there is variability in the incidence of this disorder, ranging from 17.4 per 100000 in the Commonwealth of Puerto Rico to 0.1 per 100000 in Venezuela (5)

There is increasing evidence that type 1 diabetes results from an interaction between a polygenic trait and various environmental risk factors $(6,7)$. Useful clues about environmental risk factors have been provided by a previous ecological analysis, which reported that the wide variation in type 1 diabetes incidence rates within Europe could be partially explained by indicators of national prosperity such as infant mortality rate and gross domestic product (8). The study also confirmed previously reported associations with milk consumption, coffee consumption, and geographical latitude (8).

The main objective of this study was to explore for Latin American countries (and the Commonwealth of Puerto Rico), by means of an ecological correlation analysis, the possible relationships between both the incidence and prevalence of childhood type 1 diabetes and selected hypothesized risk factors, including race/ethnicity, geographical latitude, breast-feeding rates, per capita coffee consumption and milk supply, and wealth-related indicators such as infant mortality rate, life expectancy at birth, and national human development index (HDI).

\section{METHODS}

\section{Incidence and prevalence of type 1 diabetes in Latin America}

Already published standardized incidence rates of type 1 diabetes in children $\leq 14$ years of age were obtained from the most recent report by the World Health Organization (WHO) DiaMond Project Group (4). The DiaMond Project oversees the maintenance of registries of children with type 1 diabetes around the world and has monitored the worldwide type 1 diabetes incidence over the last 15 years (9). Approximately 24 of these registries operate in the Region of the Americas.

Already published estimated prevalence rates of type 1 diabetes in children $\leq 14$ years of age were obtained from a recently published comprehensive review on the incidence and prevalence of diabetes in the Americas (5).

\section{Indicators}

Publicly available resources were researched via the World Wide Web to obtain appropriate data on the selected indicators. Due to the fact that specific data on cities or regions were seldom available, we used countrylevel data for this study.

We used several data sources (10-12) to obtain for each country in our study the proportion (percentage) of its population that is Amerindian-only (not including persons of mixed ancestry).

Geographical latitude (as degrees north or degrees south) was obtained from the "World Clock - Time Zones" page on the Internet (13). When diabetes incidence data were reported for a specific city or region in a country, the specific geographical latitude of that city or region was obtained; otherwise, the geographical latitude of the country's capital was used.

Information on life expectancy at birth (both sexes combined, for years 1985-1990) and on infant mortality (for years 1985-1990) was obtained from the United Nations Population Division (14). Data on the human development index, which is a combined measure of adult literacy, life expectancy, and gross domestic product per capita, were obtained from the United Nations Development Program (15).

Per capita consumption of coffee (as $\mathrm{kg}$ per person per year) for 1996 was obtained from the World Resources Institute (16), and the per capita supply (as $\mathrm{kg}$ per year) of milk and milk products (except butter) for 1990 was obtained from the Food and Agriculture Organization of the United Nations (17).
The exclusive breast-feeding rate ( $<4$ months of age) and the continued breast-feeding rate (12-15 months of age) for years ranging from 1993 to 2000 were obtained from the United Nations Children's Fund (UNICEF) (18).

\section{Statistical analysis}

All of the variables in this study are continuous; therefore, correlation coefficients were utilized to describe the direction and strength of the association among the variables. Because the data are not normally distributed and the sample size is small, the Spearman nonparametric correlation coefficient was the chosen statistical procedure (19). For analysis purposes, the measure of latitude was defined as nondirectional deviation, where only the number of degrees of deviation from the equator was considered (i.e., north and south have no meaning). Statistical analysis was performed using SAS software (20).

\section{RESULTS}

Table 1 presents previously published childhood type 1 diabetes standardized incidence rates as well as estimated prevalence rates in children aged 14 years of age and younger from Latin American countries $(4,5)$. While the estimated prevalence of type 1 diabetes was available for almost all countries (19 of 20), incidence data were available for only about half of them (11 of 20). However, incidence and prevalence showed a strong positive correlation $(r=0.94 ; P<0.001)$. As previously reported $(4,5)$, the incidence rate showed a wide range, from 0.1 per 100000 in Venezuela to 17.4 per 100000 in Puerto Rico. Estimated prevalence ranged from 0.3 per 10000 in Veracruz, Mexico, to 6.4 per 10000 in Puerto Rico.

Table 2 shows the selected indicators for each Latin American country in our study. Geographic latitude ranged from 4.38 degrees to 23.08 degrees in the Northern Hemisphere and from 0.14 degrees to 34.53 degrees in the Southern Hemisphere. 
The proportion of Amerindians in the general population ranged from zero in Cuba and the Dominican Republic to $55 \%$ in Bolivia.

The infant mortality rate per 1000 births ranged from 12.9 in Cuba to 90.1 in Bolivia. Life expectancy at birth ranged from 57.3 years in Bolivia to 74.8 years in Costa Rica. The national HDI ranged from 0.548 in Bolivia to 0.931 in Chile.

The rate of exclusive breast-feeding for less than 4 months ranged widely among the countries in the study. It was lowest in Paraguay and Venezuela (7.1\%) and highest in Peru and Bolivia (62.7\% and $60.9 \%$, respectively). The rate of continued breast-feeding for 12 to 15 months of age ranged from $21.0 \%$ in Costa Rica to $83.2 \%$ in Guatemala.

Per capita consumption of coffee ranged from $0.2 \mathrm{~kg}$ per year in Paraguay to 4.6 in Costa Rica. The per capita supply of milk and milk products (except butter) ranged from $25.11 \mathrm{~kg}$ per year in Bolivia to 167.05 in Argentina.
TABLE 1. Reported type 1 diabetes incidence (with $95 \%$ confidence interval $(95 \% \mathrm{Cl})$ ) and estimated prevalence in children $\leq 14$ years of age in Latin American countries

\begin{tabular}{lccc}
\hline & \multicolumn{2}{c}{$\begin{array}{c}\text { Type 1 diabetes } \\
\text { incidence } \times 10000\end{array}$} & $\begin{array}{c}\text { Type 1 diabetes } \\
\text { estimated prevalence } \\
\times 10000\end{array}$ \\
\cline { 2 - 3 } Country (Region/city) & Incidence & $95 \% \mathrm{Cl}$ & 4.3 \\
\hline Argentina (Avellaneda) & 6.5 & $4.31-9.51$ & 4.0 \\
Brazil (São Paulo) & 8.0 & $5.53-11.14$ & 1.4 \\
Chile (Santiago) & 1.6 & $1.28-2.04$ & 1.8 \\
Colombia (Bogota) & 3.8 & $2.88-4.93$ & 2.5 \\
Cuba & 2.9 & $2.63-3.24$ & 0.3 \\
Mexico (Veracruz) & 1.5 & $0.70-2.94$ & 1.0 \\
Paraguay & 0.9 & $0.71-1.11$ & 0.4 \\
Peru (Lima) & 0.4 & $0.22-0.61$ & 6.4 \\
Puerto Rico & 17.4 & $16.25-18.63$ & 4.9 \\
Uruguay (Montevideo) & 8.3 & $5.38-12.10$ & $\ldots$ \\
Venezuela (Caracas) & 0.1 & $0.09-0.18$ & 0.6 \\
Bolivia & $\ldots$ & $\ldots$ & 0.8 \\
Costa Rica & $\ldots$ & $\ldots$ & 2.5 \\
Dominican Republic & $\ldots$ & $\ldots$ & 1.9 \\
Ecuador & $\ldots$ & $\ldots$ & 0.5 \\
El Salvador & $\ldots$ & $\ldots$ & 0.4 \\
Guatemala & $\ldots$ & $\ldots$ & 0.4 \\
Honduras & $\ldots$ & $\ldots$ & 0.5 \\
Nicaragua & $\ldots$ & $\ldots$ & 1.1 \\
Panama & $\ldots$ & & \\
\hline
\end{tabular}

a The ellipsis points (. . .) indicate that the information was not available.

TABLE 2. Various ecological indicators for Latin American countries

\begin{tabular}{|c|c|c|c|c|c|c|c|c|c|}
\hline Country (Region/city) & $\begin{array}{l}\text { Geographic } \\
\text { latitude } \\
\text { (degrees }^{\text {from }} \\
\text { equator) }^{\mathrm{a}}\end{array}$ & $\begin{array}{l}\text { Amerindian } \\
\text { (\% of } \\
\text { country } \\
\text { total } \\
\text { population) }\end{array}$ & $\begin{array}{c}\text { Infant } \\
\text { mortality } \\
\times 1000 \\
\text { births }\end{array}$ & $\begin{array}{l}\text { Life } \\
\text { expectancy } \\
\text { at birth } \\
\text { (yr) }\end{array}$ & $\begin{array}{c}\text { Human } \\
\text { development } \\
\text { index }\end{array}$ & $\begin{array}{c}\text { Exclusive } \\
\text { breast-feeding } \\
\text { rate } \\
\text { (<4 months })\end{array}$ & $\begin{array}{l}\text { Continued } \\
\text { breast- } \\
\text { feeding } \\
\text { rate } \\
(12-15 \\
\text { months) }\end{array}$ & $\begin{array}{l}\text { Per capita } \\
\text { consumption } \\
\text { of coffee } \\
\text { (kg per yr) }\end{array}$ & $\begin{array}{c}\text { Per } \\
\text { capita } \\
\text { supply } \\
\text { of milk } \\
\text { and milk } \\
\text { products } \\
\text { (kg per yr) }\end{array}$ \\
\hline Argentina (Avellaneda) & $34.20 \mathrm{~S}$ & 1.0 & 27.1 & 70.8 & 0.910 & $\ldots{ }^{b}$ & $\ldots$ & 1.0 & 167.05 \\
\hline Colombia (Bogota) & $4.38 \mathrm{~N}$ & 1.0 & 41.4 & 67.6 & 0.801 & 33.5 & 49.4 & 2.4 & 92.38 \\
\hline Cuba & $23.08 \mathrm{~N}$ & 0.0 & 12.9 & 74.1 & 0.877 & 46.0 & 29.2 & 1.0 & 133.09 \\
\hline Mexico (Veracruz) & $19.11 \mathrm{~N}$ & 14.0 & 39.5 & 69.6 & 0.876 & 37.5 & 32.1 & 0.6 & 102.46 \\
\hline Paraguay & $25.15 \mathrm{~S}$ & 3.0 & 46.7 & 67.6 & 0.784 & 7.1 & 39.8 & 0.2 & 55.76 \\
\hline Peru (Lima) & $12.06 \mathrm{~S}$ & 45.0 & 68.0 & 64.1 & 0.753 & 62.7 & 77.5 & 0.5 & 43.29 \\
\hline Puerto Rico & $18.29 \mathrm{~N}$ & 0.1 & 13.8 & 74.6 & . . & $\ldots$ & $\ldots$ & 3.4 & $\ldots$ \\
\hline Dominican Republic & $18.30 \mathrm{~N}$ & 0.0 & 54.1 & 64.5 & 0.699 & 16.0 & 31.7 & 2.4 & 64.74 \\
\hline Ecuador & $0.14 \mathrm{~S}$ & 25.0 & 57.1 & 66.8 & 0.758 & 28.8 & 62.8 & 1.5 & 85.69 \\
\hline El Salvador & $13.40 \mathrm{~N}$ & 10.0 & 54.0 & 63.2 & 0.651 & 21.2 & 65.1 & 2.4 & 63.88 \\
\hline Guatemala & $14.38 \mathrm{~N}$ & 44.0 & 65.0 & 59.6 & 0.592 & 47.0 & 83.2 & 1.8 & 37.49 \\
\hline Honduras & $14.05 \mathrm{~N}$ & 7.0 & 53.1 & 64.3 & 0.563 & 42.4 & 62.6 & 1.7 & 77.03 \\
\hline Nicaragua & $12.06 \mathrm{~N}$ & 5.0 & 65.0 & 62.0 & 0.743 & 29.4 & 48.9 & 1.2 & 59.01 \\
\hline Panama & $8.57 \mathrm{~N}$ & 6.0 & 29.6 & 71.5 & 0.883 & 32.0 & 34.2 & 1.7 & 56.86 \\
\hline
\end{tabular}

\footnotetext{
a $\mathrm{S}=$ South; $\mathrm{N}=$ North.

${ }^{\mathrm{b}}$ The ellipsis points (...) indicate that the information was not available.
} 
TABLE 3. Correlation between indicators and type 1 diabetes incidence and prevalence in Latin American countries

\begin{tabular}{|c|c|c|c|c|c|c|}
\hline \multirow[b]{2}{*}{ Ecological indicator } & \multicolumn{3}{|c|}{ Incidence } & \multicolumn{3}{|c|}{ Prevalence } \\
\hline & $r^{\mathrm{a}}$ & $P^{\mathrm{b}}$ & No. ${ }^{c}$ & $r$ & $P$ & No. \\
\hline Latitude (nondirectional deviation) & -0.22 & 0.519 & 11 & -0.30 & 0.221 & 19 \\
\hline Infant mortality (per 1000 births) & -0.34 & 0.312 & 11 & -0.49 & 0.034 & 19 \\
\hline Life expectancy at birth & 0.43 & 0.189 & 11 & 0.55 & 0.016 & 19 \\
\hline Human development index & 0.40 & 0.258 & 10 & 0.50 & 0.034 & 18 \\
\hline Exclusive breast-feeding (for first 4 months of life) & 0.22 & 0.606 & 8 & -0.26 & 0.333 & 16 \\
\hline Per capita milk supply per year & 0.70 & 0.025 & 10 & 0.55 & 0.018 & 18 \\
\hline
\end{tabular}

a $r=$ Spearman correlation coefficient.

${ }^{\mathrm{b}} P=$ value for a two-tailed test that $r=0$.

${ }^{\mathrm{c}}$ No. $=$ number of pairs.

Table 3 presents the results of the correlation analyses for type 1 diabetes incidence and type 1 diabetes prevalence separately. Regarding incidence, a strong negative correlation was found with the proportion of Amerindians in the total population $(r=$ $-0.75 ; P=0.008)$. A positive correlation was found with the per capita milk supply per year $(r=0.70 ; P=0.025)$. No significant correlations with incidence were found with any of the other indicators.

Similar to incidence, prevalence showed a strong negative correlation with the proportion of Amerindians in the total population $(r=-0.78 ; P<$ $0.0001)$ as well as a positive correlation with per capita milk supply $(r=0.55$; $P=0.018)$. Two other indicators showed significant positive correlation with prevalence of the disease: life expectancy at birth $(r=0.55 ; P=0.016)$ and national HDI ( $r=0.50 ; P=0.034)$. Infant mortality rate showed a significant negative correlation $(r=-0.49 ; P=$ $0.034)$. No correlation was found with the other indicators.

\section{DISCUSSION}

Previous studies on the incidence of childhood type 1 diabetes in Latin American countries have indicated the overall rate as being very low, low, or intermediate (4). Nevertheless, the burden to individuals and society is high (21). In general, incidence is lower than that reported for Spain and Portugal (4), two southern European countries that significantly contributed to the population composition of most of today's Latin American countries. Only Puerto Rico shows what is considered to be a high incidence rate $(4,5)$.

Overall, the results of this ecological analysis suggest an association between the ethnic/race composition of the population and the incidence as well as the prevalence of type 1 diabetes. Both incidence and prevalence were strongly negatively correlated with the proportion of Amerindians in the population. This strong negative correlation for both incidence and prevalence suggests that the reported lower incidence of type 1 diabetes in some Latin American countries could be partially explained by a low genetic susceptibility to diabetes in Amerindians, by low levels of exposure to unidentified risk factors, or by high levels of exposure to unidentified protecting factors in this population group. The results of previous studies indicate that both Amerindian ancestry and haplotypes of Native American origin confer protection against type 1 diabetes $(22,23)$. Furthermore, the incidence of type 1 diabetes in the metropolitan region of Santiago (the main urban nucleus of Chile) has been estimated to be 2.36 per 100 000, while amongst the aboriginal Mapuche population living in southern Chile the incidence rate is 0.42 cases per $100000(24,25)$.
An alternative explanation for our findings is that because of possible lower standards of health care among Amerindians, many cases of type 1 diabetes may pass undetected and eventually die with either no diagnosis or a different diagnosis.

Other researchers in Latin America have suggested that the incidence of type 1 diabetes generally increases proportionally with the size of the Caucasoid population in a particular country. ${ }^{3}$

We found a positive correlation between per capita milk supply and both type 1 diabetes incidence and prevalence. Similarly, an ecological study in Europe found a positive correlation between milk consumption and the incidence of type 1 diabetes (8). In addition, a direct association between cow milk intake and the incidence of type 1 diabetes was reported in Sardinia, an Italian island that has the world's highest reported incidence of type 1 diabetes (26). Furthermore, a small harmful effect of the early introduction of cow's milk in infants was suggested by a meta-analysis of retrospective studies (27).

\footnotetext{
Sereday M, Franco L, Carrasco E, Aschner $\mathrm{P}_{\text {, }}$ Mateo de Acosta O, Jimenez J, et al. Incidence of insulin-dependent diabetes mellitus (IDDM) in Iberian heritage populations: positive association with Caucasian ethnicity. 15th International Diabetes Federation Congress (Kobe, Japan, November 1994); abstract 08A3OP0702.
} 
Results from previous case-control studies in Latin America suggest that a shorter duration of exclusive breastfeeding and early exposure to cow's milk and solid foods are risk factors for type 1 diabetes $(28,29)$. The abovementioned meta-analysis of retrospective studies (27) suggests a small protective effect of breast-feeding. However, prospective studies conducted more recently have not found such an association $(30,31)$. Similar to these latter studies $(30,31)$, our study did not find a correlation between breast-feeding (either for less than 4 months or continued breast-feeding for 12 to 15 months) and type 1 diabetes. It is important to notice that breast-feeding data used in our analyses were collected five to eight years after the time for which incidence and prevalence data were reported. During this period of five to eight years an extensive campaign to increase breastfeeding took place with varying success across Latin American countries, which may have influenced the lack of correlation found in our study.

Our study did not corroborate previous reports of association of type 1 diabetes with coffee consumption. The above-mentioned ecological study in Europe (8) reported that association. A Finnish study reported an increased risk for type 1 diabetes in children who consume coffee or tea regularly (32).

We did not find a correlation of either incidence or prevalence of type 1 diabetes with geographic latitude. The most recent report by the WHO DiaMond Project Group (4) includes incidence data from 100 registries in 50 countries, including the Latin American countries in this study. That research indicates that the earlierreported polar-equatorial gradient in the incidence of type 1 diabetes in the Northern Hemisphere does not seem to be as strong as previously assumed. Furthermore, such a gradient has not been reported in the Southern Hemisphere, where several of the Latin American countries in this study are located.

The above-mentioned ecological study in Europe (8) concluded that indicators of national prosperity, such as infant mortality rate and gross domestic product per capita, could explain a significant portion of the large variation in type 1 diabetes incidence rates across this continent. Our prevalence analysis supports their finding, but our incidence analysis does not. This discrepancy between incidence and prevalence could be related to the fact that data on incidence were not available for half the countries in our study. It could also be argued that incidence of type 1 diabetes is in general much lower and varies less strikingly in Latin America than in Europe. Also, factors linked to industrialization and changes in lifestyles are still at a lower level in Latin American countries than they are in European nations.

Although our study presents some very intriguing findings, it is also important to discuss its limitations. The limitations of ecologic data for making causal inferences have been reviewed in depth (33). One disadvantage of this kind of analysis is that the joint distribution of exposure and health remains unknown (ecological fallacy), which leads to possible distortion of association between exposure and outcome. Other disadvantages include the inherent limitations to using existing databases and difficulties in controlling for confounders.

Most of the available incidence data for Latin America pertain to a city or a region within a country. However, we obtained indicators for the country level and did not account for differences between the country and the specific city or region. Also, for some countries some of the indicators were only available for years after the incidence data period.
Amerindian ethnicity was used as surrogate for personal ancestry, which in turn is considered to be a potentially misleading substitute for genetic ancestry. However, a recent study of the DNA of 52 human groups from around the world suggested that selfreported population ancestry likely provides a suitable proxy for genetic ancestry (34).

Another fact to take into consideration is that although the initial Amerindian inhabitants were eliminated as a distinct culture in some Latin American countries, and thus their current proportion in the general population is almost absent, they made a significant genetic contribution to the current population of some of these countries (35).

Finally, caution is required in terms of the reliability of some of the information provided by the publicly available resources that we used.

\section{CONCLUSION}

Our results suggest the presence of the Amerindian component of the population in Latin America provides protection against childhood-onset type 1 diabetes. In addition, our results confirm reports from other countries and regions of the world of the association between type 1 diabetes and milk consumption. Further studies are needed to develop and test potential genetic and environmental hypotheses that could help to better understand the interplay between genetic susceptibility and environment in type 1 diabetes across different ethnic groups. Clearly, continuing and expanding surveillance for childhood-onset type 1 diabetes across Latin America, including specific surveillance of the various race/ethnic groups, represents one of the most important strategies for improving our understanding of the multifactorial causes of the disease and ultimately preventing it. 


\section{REFERENCES}

1. Rewers M, LaPorte RE, King H, Tuomilehto J, Diabetes Epidemiology Research International Group. Trends in the prevalence and incidence of diabetes: insulin-dependent diabetes mellitus in childhood. World Health Stat Q. 1990;41:179-89.

2. Karvonen M, Tuomilehto J, Libman I, LaPorte R. A review of the recent epidemiological data on the worldwide incidence of type 1 (insulindependent) diabetes mellitus. World Health Organization DiaMond Project Group. Diabetologia. 1993;36:883-92.

3. Karvonen M, Pitkäniemi M, Pitkäniemi J, Kohtamäki K, Tajima N, Tuomilehto J. Sex difference in the incidence of insulin-dependent diabetes mellitus: an analysis of the recent epidemiological data. Diabetes Metab Rev. 1997;13:275-91.

4. Karvonen M, Viik-Kajander M, Moltchanova E, Libman I, LaPorte R, Tuomilehto J. Incidence of childhood type 1 diabetes worldwide. Diabetes Mondiale (DiaMond) Project Group. Diabetes Care. 2000;23(10):1516-26.

5. Barceló A, Rajpathak S. Incidence and prevalence of diabetes mellitus in the Americas. Rev Panam Salud Publica. 2001;10(5):300-8.

6. Davies JL, Kawaguchi Y, Bennett ST, Copeman JB, Cordell HJ, Pritchard LE, et al. A genome-wide search for human type 1 diabetes susceptibility genes. Nature. 1994;371 (6493):130-6.

7. Akerblom HK, Knip M. Putative environmental factors in type 1 diabetes. Diabetes Metab Rev. 1998;14:31-67.

8. Patterson CC, Dahlquist G, Soltesz G, Green A. Is childhood-onset type I diabetes a wealthrelated disease? An ecological analysis of European incidence rates. Diabetologia. 2001;44 Suppl 3:B9-16.

9. WHO Multinational Project for Childhood Diabetes. WHO Diamond Project Group. Diabetes Care. 1990;11(10):1062-8.

10. Jordán Pando R. Poblaciones indígenas de América Latina y el Caribe. México: Organización de las Naciones Unidas para la Agricultura y la Alimentación/Instituto Indigenista Interamericano; 1990.

11. Matos Mar, J. Población y grupos étnicos de América. América Indígena. 1993;53(4):155234.

12. United States, Central Intelligence Agency. The 1990 CIA world factbook [Internet page]. Available from: http://www.lib.umd.edu/ ETC/ReadingRoom/Historical/USCI/. Accessed 18 February 2004.

13. Thorsen S. The world clock - time zones [Internet page]. Available from: http://www. timeanddate.com/worldclock. Accessed 17 February 2004.

14. United Nations Population Division. World population prospects: the 2002 revision population database [Internet page]. Available from: http://esa.un.org/unpp/index.asp? panel=3. Accessed 17 February 2004.

15. United Nations Development Programme. Technical and statistical notes. In: UNDP. Human development report 1990. Available from: http://hdr.undp.org/reports/global/ 1990/en/pdf/hdr_1990_technotes.pdf [Internet site]. Accessed 17 February 2004

16. World Resources Institute. Coffee consumption per capita [Internet page]. Available from: http://earthtrends.wri.org/text/ENG/ variables/789.htm. Accessed 4 August 2003.

17. Food and Agriculture Organization of the United Nations. Food balance sheets. [Internet page]. Available from: http://faostat.fao. org $/$ faostat $/$ form? collection=FBS\&Domain= FBS\&servlet $=1 \&$ hasbulk $=\&$ version $=$ ext $\&$ language $=$ EN . Accessed 17 February 2004

18. United Nations Children's Fund. UNICEF global database. Breastfeeding indicators [Internet page]. Available from: http://www. childinfo.org/eddb/brfeed/test/database. $\mathrm{htm}$. Accessed 24 July 2003.

19. Lehmann EL, D'Abrera HJM. Nonparametrics: statistical methods based on ranks. Revised 1st ed. Englewood Cliffs: Prentice-Hall; 1998.

20. SAS Institute Inc. SAS version 8.2 [computer program]. Cary: SAS Institute Inc; 1999-2001.

21. Barceló A, Aedo C, Rajpathak S, Robles S. The cost of diabetes in Latin America and the Caribbean. Bull World Health Organ. 2003;81 (1):19-27.

22. Erlich HA, Zeidler A, Chang J, Shaw S, Raffel LJ, Klitz W, et al. HLA class II alleles and susceptibility and resistance to insulin dependent diabetes mellitus in Mexican-American families. Nat Genet. 1993;3(4):358-64.

23. Shaw SJ, Vadheim CM, Rotter JI, Costin G, Beshkov Y, Zeidler A. Ancestral origin of insulin-dependent diabetes in MexicanAmericans. Int J Epidemiol. 1992;21(4):725-9.

24. Larenas G, Montecinos A, Manosalva M, Barthou M, Vidal T. Incidence of insulindependent diabetes mellitus in the IX region of Chile: ethnic differences. Diabetes Res Clin Pract. 1996;34:S147-51.

25. Erlich HA, Zeidler A, Chang J, Shaw S, Raffel LJ, Klitz W, et al. HLA class II alleles and susceptibility and resistance to insulin dependent diabetes mellitus in Mexican-American families. Nat Genet. 1993;3(4):358-64.
26. Muntoni S, Loddo S, Stabilini M, Stabilini S, Muntoni S. Cow's milk consumption and IDDM incidence in Sardinia. Diabetes Care. 1994:17:346-7.

27. Gerstein HC. Cow's milk exposure and type 1 diabetes: a critical overview of the clinical literature. Diabetes Care. 1994;17:13-20.

28. Gimeno SG, de Souza JM. IDDM and milk consumption. A case-control study in Sao Paulo, Brazil. Diabetes Care. 1997;20(8):125660.

29. Pérez-Bravo F, Carrasco E, Gutiérrez-López MD, Martínez MT, López G, García de los Ríos M. Genetic predisposition and environmental factors leading to the development of insulin-dependent diabetes mellitus in Chilean children. J Mol Med. 1996;74(2):105-9.

30. Couper JJ, Steele C, Beresford S, Powell T, McCaul K, Pollard A, et al. Lack of association between duration of breast-feeding or introduction of cow's milk and development of islet autoimmunity. Diabetes. 1999:48:2145-9.

31. Hummel M, Schenker M, Fuchtenbusch M, Ziegler A-G. No major association of breast feeding, vaccinations and childhood viral diseases with early islet autoimmunity in the German BABYDIAB Study. Diabetes Care. 2000;23:969-74.

32. Virtanen SM, Rasanen L, Aro A, Ylonen K, Lounamaa $\mathrm{R}$, Akerblom $\mathrm{HK}$, et al. Is children's or parents' coffee or tea consumption associated with the risk for type 1 diabetes mellitus in children? Childhood Diabetes in Finland Study Group. Eur J Clin Nutr. 1994; 48(4):279-85

33. Morgenstern $\mathrm{H}$. Uses of ecologic analysis in epidemiological research. Am J Public Health. 1982:72:1336-44.

34. Rosenberg NA, Pritchard JK, Weber JL, Cann HM, Kidd KK, Zhivotovsky LA, et al. Genetic structure of human populations. Science. 2002;298(5602):2381-5.

35. Thieme FP. The geographic and racial distribution of $\mathrm{ABO}$ and $\mathrm{RH}$ blood types and tasters of PTC in Puerto Rico. Am J Hum Genet. 1952; 4:94-112.

Manuscript received 30 September 2003. Revised version accepted for publication 12 March 2004. 
RESUMEN Objetivo. Explorar para América Latina, mediante un análisis de correlación ecológico, las posibles relaciones entre tanto la incidencia como la prevalencia de diabetes sacarina tipo 1 con inicio en la niñez y algunos factores etiológicos hipotéticos, entre ellos la raza o etnia, la latitud geográfica, las tasas de lactancia materna, el abastecimiento de leche, el consumo de café per cápita y algunos indicadores de situación económica, tales como la tasa de mortalidad de menores de un año, la esperanza de vida al nacer y el índice nacional de desarrollo humano.

Métodos. Se usaron datos publicados recientemente acerca de la incidencia y prevalencia de diabetes tipo 1 en niños menores de 15 años en países latinoamericanos. Se escogieron los indicadores de riesgo en función de las hipótesis de carácter genético y ambiental que se contemplan actualmente. Los datos acerca de los indicadores se obtuvieron de fuentes públicas. Se emplearon coeficientes de correlación de Pearson para medir la asociación entre tanto la incidencia como la prevalencia de diabetes tipo 1 y los indicadores elegidos.

Resultados. Se detectó una fuerte correlación inversa entre la proporción de amerindios en la población de un país y la incidencia $(r=-0,75 ; P=0,008)$ y prevalencia estimada $(r=0,55 ; P=0,018)$ de diabetes tipo 1 de aparición en la niñez. El abastecimiento de leche per cápita mostró una fuerte correlación directa con la incidencia $(r=0,70$; $P=0,025)$ y la prevalencia $(r=0,55 ; P=0,018)$ de diabetes. Los indicadores de situación económica mostraron correlación con la prevalencia pero no con la incidencia.

Conclusiones. Según nuestros resultados, la presencia del componente amerindio en la población de América Latina protege contra la diabetes tipo 1 con incio en la niñez. Nuestros resultados también confirman la asociación notificada anteriormente en otros países y partes del mundo entre la diabetes tipo 1 y el consumo de leche. Se necesitan más estudios para formular y poner a prueba nuevas hipótesis de orden genético y ambiental que ayuden a entender mejor la interacción entre la susceptibilidad genética y factores ambientales en la aparición de diabetes tipo 1 en distintos grupos étnicos.

\title{
Global Forum for Health Research
}

$\begin{array}{cl}\text { Dates: } & 16-20 \text { November } 2004 \\ \text { Location: } & \text { Hotel Sheraton Centro Histórico } \\ & \text { Mexico City, Mexico }\end{array}$

Forum 8, the eighth annual meeting of the Global Forum for Health Research, will deal with health research to achieve the Millennium Development Goals (MDGs), which were adopted by the United Nations in 2000. At present rates of progress, the MDGs will not be reached for a majority of the world's population. Consequently, Forum 8 will focus on global efforts to expand health research in neglected areas to support the achievement of the MDGs.

Forum 8 will include plenary sessions, panel discussions, workshops, poster sessions, and other activities to promote the exchange of ideas among participants.

The registration fee for the meeting is US\$ 100 for persons from low- and middle-income countries and US\$500 for participants from high-income countries.

\author{
Information: \\ Convention Center \\ Barrilaco 410 \\ Lomas de Chapultepec \\ CP 11000 \\ Mexico DF, Mexico \\ Telephone: 5255 5201-7930 • Fax: 5255 5520-9284 \\ E-mail: forum8@convention-center.net \\ Web site: http://www.globalforumhealth.org/Forum8
}

